\title{
ACCOUNTING AND SMALL AND MEDIUM-SIZED ENTERPRISES: CASE FROM THE MEMBERS OF THE EX-MIGRANT WORKER COOPERATION OF KULON PROGOIN DAERAH ISTIMEWA YOGYAKARTA INDONESIA
}

\author{
I PUTU SUGIARTHA SANJAYA ${ }^{1}$, Y. HENDRASURYADHARMA ${ }^{2}$ \\ ALOYSIUS GUNADI BRATA ${ }^{3} \&$ SURYO ADI PRAMANA ${ }^{4}$ \\ ${ }^{1}$ Lecturer Department of Accounting, Universitasatma Jaya Yogyakarta, Indonesia \\ ${ }^{2}$ Lecturer Department of Civil Engineering, Universitasatma Jaya Yogyakarta, Indonesia \\ ${ }^{3}$ Lecturer Department of Development Economics, Universitasatma Jaya Yogyakarta Indonesia \\ ${ }^{4}$ Lecturer Department of Sociology, Universitasatma Jaya Yogyakarta Indonesia
}

\section{ABSTRACT}

The objective of this research is, to explore accounting practice at small and medium-sized enterprises (SMEs). Migrant workers commonly built institution as cooperation, for Ex-Migrant Workers in Yogyakarta Indonesia. The members of cooperation have small business, such as palm sugars, food, etc. Some of their products will sell at area of cooperation. Commonly, they make business, such as buy raw materials, pay employee, and have some plant, property and equipment. Finished products will be sold to domestic market and international market, because they have good experience when they were migrant workers in foreign countries, such Singapore, Malaysia, U.S., Europe, and etc. based on our deep observation and interview, we find that, they do not like to make recording transaction and reporting economics events. They are very busy for their business and they need more time for their job, than for accounting. These are a reality in Indonesia. Commonly, SMEs in Indonesia do not have accounting. They always use their estimation. This is a challenge for implementation of Financial Accounting Standard for SMEs. It will start on January $1^{\text {st }}, 2018$.

KEYWORDS: SMEs, Ex-Migrant Workers, Accounting \& Financial Accounting Standard

Received: Sep 14, 2017; Accepted: Oct 04, 2017; Published: Oct 28, 2017; Paper Id.: IJAFMRDEC20171

\section{INTRODUCTION}

This study aims to analyze and explore how accounting is applied by Small and Medium Sized Enterprises (SMEs). The enterprises are owned and controlled by cooperation members of ex-migrant workers. This study is important because the Accounting Standards Board of the Indonesian Institute of Accountants will set new standards of Financial Accounting Standards Micro, Small and Medium Enterprises (SAK EMKM) for SMEs on January 1, 2018. This standard is important for immediately enforced because SMEs is very difficult to apply the Financial Accounting Standards Entity without Public Accountability. Based on the results of the Focus Group Discussion in the Linkage Program, SMEs must submit their financial statements to special credit term for some

\footnotetext{
We would like to thank for Ministry of Research, Technology and Higher Education of the Republic of Indonesia for funding this research based on contract number: 045/HB-LIT/IV/2017 for schema Research of Social, Humanities, a Education. This paper is part of our research about Social Movement of Cooperation forEx-Migrant Workers Community and their Family (Study in KulonProgo Regency of Daerah Istimewa Yogyakarta). This paper also have presented on International Conference on Innovative Research in Science, Technology \& Management, at National University of Singapore, 16-17 September 2017. I would like to thank participants for comments and suggestions
} 
banks. It is called Credit of People Business (KUR). Therefore, this research will explore the reality of accounting process at SMEs, formed by the members of the ex-migrant worker cooperation of Kulon Progo.

Researchers are interested in conducting research for the members of the ex-migrant worker cooperation of Kulon Progo because, this cooperation is the only one in Indonesia, founded by the ex-migrant workers of Kulon Progo. In addition, the members of this cooperation also run their business activities. The business activity may be called as SMEs activities. The members of the ex-migrant worker cooperation of Kulon Progo, have a lot of business activities. They also have work experience abroad, influencing them more sensitive enough to using natural resources, for their start up business. There are the members of the ex-migrant worker cooperation of Kulon Progo, operating transportation business. There are also cooperation members to produce palm sugar, various foods, crafts, building material, and so forth.

Every activity undertaken by the members of the ex-migrant worker cooperation of Kulon Progo is no accounting process to be done. At the beginning, the transport business bought a truck and now there are two trucks. This purchase already records as the assets. To operate the truck, this business requires fuel. To keep normal process on the road, trucks are routinely serviced. To run the truck, this business requires a driver. For declining value of truck, the businesses depreciate the truck's value every time. The activities are related to the loads that occur. There are other expenses. During operation, the truck definitely gets the money from dropping material to the destination. It means that there is money coming in or billing to other parties into the business. It will have an impact on the increase in assets.

For palm sugar, this business also has transactions that must be recorded and reported. This business has a production process starting from the purchase of raw materials such as coconut sugar from farmers. Coconut sugar is smoothed by machine. The process indicates there is a production activity from raw materials to finishing palm sugar. In accounting, there is the purchase of raw materials. The purchase of raw materials should be recorded. Processing of raw materials using human labor is also recorded as labor expense. The machine is used to process the raw material and it must be depreciated as depreciation expense. Machines are powered by electricity and there is an electric expense. There is packing activities and there is packing expense. All activities ranging from the procurement of raw materials, process, and until the ready sale of palm sugar products should be recorded.

The next activity is the making of building material which is done by the members of the ex-migrant worker cooperation of Kulon Progo. In the beginning; it puts sand in the river. It needs labor to put the sand. It requires cement and gravel to mix materials. Machines are needed in the manufacture of brickworks. The sand, cement, water, gravel are mixed, by special machine. After the process, the mixture is spilled on each mold and pressed with a press machine, to produce a brick with good quality. Based on this process, there are some expenses that should be recorded, starting on labor to put sand, cement, labor, and depreciation of machine. Based on the three types of SMEs business, the question arises on, whether the SMEs formed by the members of the ex-migrant worker cooperation of Kulon Progo records and reports of financial information.

\section{THEORETICAL REVIEW}

\section{Accounting}

According to Weygandt et al.(2016), accounting is an accounting information system providing these insights. Accounting contains three main activities, such as identifying, recording, and communicating the economic events of an organization for stakeholders. As a first step for the accounting process, a company identifies the economic events relevant 
to its business. For example, SMEs sells palm sugar. SMEs sell building material. SMEs perform to drop material. SMEs sell tofu and temple as its products. After identification, the next step is to record the events chronologically, to give a story about its financial activities. Recording contains the keeping of a systematic, chronological record of events, and measured in monetary units. In the final process, the company communicates the information, as an accounting report that has been needed by users. It is commonly called financial statements to meaningful financial reports; the company should report the recorded data in a standardized manner. A very important point is the ability of a user, to analyze and interpret the reported information.

According to Wolk et al. (2001), measurement is a very important aspect in accounting. Measurement can be defined as an assignment of numbers, for the attributes or properties of the measured object, if the number given to the object is an actual measurement of the desired property. This is often referred to as direct measurement. An indirect measurement of an expected attribute is one thing, to do with roundabout means, such as replacement cost of ending inventory using the retail price.

According to Byrd and Megginson (2017), accounting information has an important meaning to achieve business success including for small business. Accounting information can be a faithful representation for decision-making in small business management such as market development decisions, pricing, and so on. The accounting information is also required in relation to credit proposal by SMEs to banks.

\section{The Users of Financial Statements}

Internal users of accounting information are the managers who plan, combine, and run the business. It includes marketing managers, production supervisors, finance directors, and company officers. The question of finance is cash sufficient to pay dividends to shareholders? Marketing; what price for cell phone will maximize the company's net income? Human resource; can we afford to give employee pay rises this year? Production management; which product line is the most profitable? Should any product lines be eliminated? To answer these and other questions, internal users need detailed information on a timely basis. Managerial accounting provides internal reports to help users make decisions about their companies. Examples are financial comparisons of operating activities, projection of income from new sales campaigns, and forecasts of cash needs for the next year. External users are individuals and organizations outside the company who want financial information about the company. Creditors such as suppliers and bankers use accounting information to evaluate the risks of granting credit or lending money. Taxing authorities want to know whether the company complies with tax laws.

\section{RESEARCH METHODS}

To get a deep and comprehensive picture, the subject of this research is the ex-migrant worker cooperation of Kulon Progo. The method used in this research is qualitative method. The main respondents in this study were the members of the ex-migrant worker cooperation of Kulon Progo. Collected data used in this study are in-depth interviews and observation. Interviews were conducted in the form of dialogue both individually and in groups with the members of the ex-migrant worker cooperation of Kulon Progo. This research also directly observes to get more information for indepth problem. Interviews and observations conducted in 2017. The location of this study is in Kulon Progo Regency because; the Regency is the only one in Indonesia has cooperation, which is founded by ex-migrant works. In-depth interviews and observations are the primary data for this study. 
For analyzing data, this study uses qualitative data analysis. According to Sekaran and Bougie (2016), the first step in qualitative data analysis is concerned with data reduction. Data reduction refers to the process of selecting, coding, and categorizing the data. Data displays may help to draw conclusions based on patterns in the reduced set of data. The model of this analysis is through the process of collecting data is reduced in the form of research findings that are relevant to the writing materials. Next, the data are presented in a narrative. Reduction and presentation of data are two components of analysis performed simultaneously with the data collection process. The next process is the conclusion that is done after the data collection process, presented, and described, then given the meaning with logical interpretation. The activities of the three components interact until the correct conclusion is obtained. If the conclusions are inadequate, retesting activities will be done by searching the data again in the field and trying to interpret it with a more focus. Thus the activity of analysis with data collection is the process of the cycle until the research is completed.

\section{RESULTS ANALYSIS}

In interviews and observations, SMEs have several types of expenses such as reparation expense, raw material expense, electric expense, wages expense, fuel expense, and depreciation expense. Some of the expenses are sometimes recorded and sometimes not recorded by SMEs. This is caused by the activity in SMEs need a lot time. In fact, there are SMEs who never record the expenses. They only remember the transactions because the process is sufficient. According to the SMEs, financial recording is not necessary because it is very easy to remember. The purchase of fuel is very easy to predict because it is based on his experience. They argue that the recording need more time. They are more interested to focus for SMEs activities than record transaction in SMEs. They are always busy and they fill very tired to accounting process. They argue that net profit is very easy to be calculated based on their memory.

In general, the members of the ex-migrant worker cooperation of Kulon Progo have not known accounting yet. In general, they recognize that, there has been no accounting process training. They feel more important for doing SMEs activities to increase their business profit than to learn the accounting process. Learning the accounting process is a waste of time. They suggest that no other party made recording and preparing financial statements. They also stated that there was no accompaniment to accounting process.

They suggest that the results of the business are profitable because they know the development of business from time to time. There is who admits business profit in the range between 3-5 million per month. The business has a financial prospect. They do not know exactly the amount of operating income every month and every year. There are the members of the ex-migrant worker cooperation of Kulon Progo develop new business (CV), such as for building materials with 4 members. They believe that, these SMEs have good prospects in the future because there is an increase in cash flow and assets such as investment in $\mathrm{CV}$.

SMEs actually have several elements of financial statements such as assets, debt, capital, income, expenses, and profits. SMEs have several fixed assets such as land, buildings, vehicles, and machine. Owners also often take money on SMEs for personal needs such as for school children. It is not recorded. There are owners of SMEs who return the money to SMEs. Net income is used to develop capital. There are some purchase transactions made on credit and there are also in cash. Cash payment is made to purchase coconut sugar from farmers. The purchase invoice is always stored until it can be calculated the purchase amount. There is an owner who discards all notes after they have finished calculating their business results. There are SMEs whose sales are done on credit. There are also sales of SMEs done in cash for the domestic market 
while the sale is done on credit for international markets. Proof of sale is always kept and there is also in the form of a checking account.

At the end of each year there are unsold products but the sold products is more than the unsold. Unsold products are not damaged. They calculate the cost of goods sold on the basis of estimates and it is not based on the record. They never receive return goods sold for the domestic market. But they received a return of goods for the international market because there is gluten in the products. SMEs always do the production although there is no order. There is the member of the ex-migrant worker cooperation of Kulon Progo, which receive KUR up to Rp500.000.000. KUR can be given by the bank, if there is a recommendation from the ex-migrant worker cooperation of Kulon Progo. However, there are also KUR, without having to get a recommendation from the ex-migrant worker cooperation of Kulon Progo because, they have been trusted by the bank.

\section{DISCUSSIONS}

Based on data from observations and interviews, they are not interested in carrying out the accounting process because, they are running out of time and effort for SMEs. They also do not want to be bothered by the accounting process. They argue that the benefits of the accounting process are lower than the benefits of doing the main job. During this time, the filing of KUR credit without the financial statements. It is not matters for the bank because SMEs always pay the installments. It causes them not to be interested in the accounting process because it does not benefit.

This view is consistent to the empirical findings, made by some researchers in Indonesia. According to Marbun (1997) in Pinasti (2007), one of the weaknesses of small businesses in Indonesia is that, they do not control and practice adequate financial system. In general, small businesses do not manage accounting records are strict and disciplined, with a regular recording in the form of daily, weekly, monthly, and so on. One reason for the absence of adequate records is that, the need for procurement of accounting records is considered to be a waste of time and money. Hariyanto (1999) in Pinasti (2007) found that, retail trading business in Purwokerto considered accounting information is not important. They do not need accounting information. Idrus (2000) in Pinasti (2007) affirmed that, SMEs do not have accounting knowledge and have not understood the recording and reporting. They feel the accounting process is not very important. Pinasti (2001) in Pinasti (2007) shown that, small traders in the traditional markets of Banyumas Regency do not organize and use accounting information in running their business. More business management is based on non-accounting information. Small traders view accounting information as unimportant. The administration of accounting records is too much of a hassle. They are more interested in working and earning income than do accounting process. They have not benefited from accounting information.

Rudiantoro and Siregar (2011) found that, some SMEs in Depok and Jakarta did not do the accounting process, starting from recording to reporting. These SMEs still rely on their memory of the transactions that occur, so they feel they do not need recording. Norkamsiah et al. (2016) conducted a case study in CV Aba Komputer. Norkamsiah et al. (2016) found that, the financial statements made by CV. Aba Computers are very simple and only income statements that are not complete. Lutfiaazahra (2015) found, there are SMEs batik craftsmen, who do not need detailed financial record. They assume that, wasting time is for accounting process. They are most interested to perform trading activities and it clearly generates more profits for their business. There is no human resources in the field of accounting and it also causes SMEs do not implement the accounting process. 
Jati et al. (2009) stressed that, SMEs are still very difficult to carry out, accounting to produce financial statements. Limitations of accounting knowledge, the complexity of the accounting process, and the assumption that financial statement are not important to them. Putra and Kurniawati (2012) showed that, SMEs in Salatiga, who have no financial report yet. The owner of SMEs only records purchases of raw materials, wages payments, payments of electricity, water and telephone charges and sales. Recording is done based on transaction type, rather than on daily transaction.

Sixpria et al. (2013) found that, SMEs in the Depok Region have not conducted and use accounting information maximally, in the management of their business. Pratama (2014) affirms that, As-Shaqi Convection in Tangerang Selatan Banten Province has insufficient human resources to manage the company's finances. The recordings are not well executed as accounts receivable, debt, assets, and sales. SMEs accounts are still mixed with the personal accounts of the owners making it difficult to determine financial activities for SMEs and personal. Siswono (2014) conducted a study in Brebes Fried Chicken who found that, these SMEs never compiled and made a financial report. There are some obstacles, such as no human resources that have the ability to make financial statements. Less time to focus on preparing financial statements because, the time is maximized in business operations.

Diacahya (2014) shows SMEs Batik Loro Lopo Solo does not have any financial report, since its establishment in 1997. The owner only records the purchase transaction of raw materials, salary payment, electricity payment, water and telephone and sales. Recording is done by type of transaction. Owners only do a simple record. Constraints for SMEs to prepare financial statements are the lack of human resources who have the ability in preparing financial statements. Employees do not have accounting education background and never participate in accounting training. They just record the cash inflow and cash outflow.

Implementation of training and mentoring for SMEs is essential to carry out the accounting process. Universities, Government, Private Parties, Village Assistance Groups, and other Organizations have a responsibility to assist SMEs because SMEs are institutions that contribute significantly to supporting the economy of Indonesia. The existence of SMEs in a village will encourage the formation of Village Owned Enterprises that become the driving force of the economy in the village. This is in accordance with "Nawa Cita" Programof President Joko Widodo. Moreover, the Financial Accounting Standards of Micro, Small and Medium Enterprises (SAK EMKM) will be applied to SMEs. This standard is a local standard for entities, without significant public accountability and entities that meet the definitions and characteristics of Law No. 20 of 2008, on SMEs and Law no. 1 of 2013 on Micro Financial Institution. The recording and reporting affirmed in this standard are historical cost and accrual basis.

Training and assisting are important. According to Kreitner and Kinicki (2013), a person's perceptions will influence his or her behavior and decisions. This perception can be constructed from training and mentoring. Perceptions of accounting information can encourage small entrepreneurs, to organize and use accounting information. Empirically, the training contributes significantly to SMEs to carry out the accounting process. Murniarti (2002) suggested that, the use of small and medium enterprise accounting information can be improved, by providing accounting training that is followed by the owner or manager. The more often a manager/owner participates in accounting training, then the probability of a company to prepare and use accounting information is higher. Lestari (2006) stated that, training experience can encourage manager's perception of financial accounting information.

Pinasti (2007) asserted that, the experience of research subjects with accounting information through stimulus implementation and use of accounting information, proved to affect perceptions regarding the benefits of accounting 
information and willingness to hold accounting records. These experiences with accounting information forms new information in the schemata, they use to interpret the value/benefit of accounting information, and change the negative perceptions of accounting information. Hanum (2013) conducted a study on small entrepreneurs in Medan City. Hanum (2013) found that, motivation has a positive effect on small entrepreneur perception of accounting information.

In addition to the provision of training and mentoring, SMEs need to be assisted by the provision of software that can be applied by using mobile phones such as Microsoft Excel application with a formula designed to facilitate SMEs in generating financial statements. This will make it easier for SMEs to do the accounting process such as Cloud-based Accounting in Ireland (Cleary and Quinn, 2016). If still on currently, the SMEs have less time to carry out the accounting process than operating SMEs that will increase SMEs profits.

The Financial Services Authority (OJK) should also encourage banks to require every KUR submission to include financial statements. The KUR distributor bank may not produce financial statements for potential SMEs. If this practice is found by OJK, law enforcement must be done because the government is willing to subsidize the interest of SMEs utilizing KUR. The reluctance of SMEs in the accounting process because there are fears related to taxes. The government should be able to provide tax holiday policies for SMEs so they are eager to build their business. Because they are uncomfortable when start to begin new business the discussions more focus on the Taxpayer Identification Number. Governments may impose a tax to SMEs for several years after they are completely stable. The tax potential for the government is large both for the central and regional governments as SMEs have various kinds of businesses. Implementation of accounting for SMEs is a must because reliable financial statement information is needed by the government to evaluate the growth of SMEs. Information will be used to take policy by the government. Incentives should be given to SMEs applying the fairly accounting process.

\section{CONCLUSIONS}

SMEs formed by the members of the ex-migrant worker cooperation of Kulon Progo, have not had the accounting process. They do not chronologically record transactions but they only rely on their memory. This is certainly potentially big mistake in decision making. Currently, financial statements have not been made by SMEs. This is a big challenge for the Government and the Board of Accounting Standards to implement SAK EMKM. Consequences should be leveled when they do not implement this SAK. The financial statement information of each SME will be very useful to measure economic growth in Indonesia. Training and mentoring in the accounting process must be given for SMEs. This research provides advice for the Government both the Central Government through the Ministry of Cooperation and SMEs and Local Government to facilitate SMEs to carry out the accounting process. The financial statements are the final process of accounting that can be used by users to make decisions. The second suggestion is universities, especially the Institute for Research and Community Service. The existing SMEs are in desperate need of assistance in mentoring and guidance on financial management including accounting process. This is big opportunity to conduct research and community service. The third recommendation is that village counseling agencies should also be given the responsibility to assist SMEs in the village. It may be a Village Owned Enterprise that can drive the economy in the village. The fourth suggestion is to private parties such as PT Angkasa Pura, who will manage the new international airport in Kulon Progo. PT Angkasa Pura can provide assistance and guidance to SMEs, for new business competition. The local banks and national commercial banks can take advantage of corporate social responsibility, to strengthen the institutions of SMEs including strengthening the financial management of SMEs. 
Finally, this research can be developed, for subsequent researchers related to Theory Acceptance Model (TAM) in information systems. The next researcher can examine the perceive usefulness and perceive ease of use in behavioral intention, to produce financial statements. Psychological studies are related to the behavior, that can encourage and change the behavior of SME managers, to implement the accounting process correctly.

\section{REFERENCES}

1. A.Lutfiaazahra (2015): "ImplementasiStandarAkuntansiKeuanganEntitastanpaAkuntabilitasPublik (SAK ETAP) pada UMKM Pengrajin Batik di Kampoeng Batik Laweyan Surakarta”, Prosiding Seminar Nasional Pendidikan EkonomidanBisnis.

2. A.Pratama (2014): “RancanganPenerapanStandarAkuntansiKeuanganEntitasTanpaAkuntabilitasPublik (SAK ETAP) pada Usaha Kecil danMenengah (UKM): StudiKasuspadaKonveksi As-ShaqiPamulang”,Skripsi. Universitas Islam NegeriSyarifHidayatullah Jakarta.

3. E. Siswono (2014): "PenerapanPenyusunanLaporanKeuanganpada Kecil MenengahBerbasisStandarAkuntansiKeuanganEntitasTanpaAkuntabilitasPublik: $\quad$ StudiKasus $\quad$ UKM Brebes Fried Chicken”,Skripsi. Universitas Dian Nuswantoro.

4. H. A. Putra, andE.P. Kurniawati (2012): "PenyusunanLaporanKeuanganuntuk Usaha Kecil danMenengah (UKM) BerbasisStandarAkuntansiKeuanganEntitasTanpaAkuntabilitasPublik (SAK ETAP)", Proceeding for Call Paper PekanIlmiahDosen FEB-UKSW.

5. H. I. Wolk, M.G. Tearney, and J.L. Dodd (2001): “Accounting Theory: A Conceptual and Institutional Approach”, $5^{\text {th }}$ Edition. South-Western College Pub.

6. H. Jati, B. Bala, and O. Nisnoni (2004): "MenumbuhkanKebiasaan Usaha Kecil MenyusunLaporanKeuangan”,JurnalBisnisdanUsahawan. Vol. 2, No. 8, pp. 210-218.

7. J. J. Weygandt, P. D. Kimmel, and D. E. Kieso (2016): “Financial Accounting: IFRS”, $3^{\text {rd }}$ Edition. Wiley.

8. M. Pinasti (2007): "PengaruhPenyelenggaraandanPenggunaanInformasiAkuntansiterhadapPersepsiPengusaha Kecil atasInformasiAkuntansi: SuatuRisetEksperimen”,JurnalRisetAkuntansi Indonesia, Vol. 10, No. 3, pp. 321-331.

9. M. J. Byrd, and L. Megginson (2017): “Small Business Management: An Entrepreneur's Guidebook”, $8^{\text {th }}$ Edition. Irwin McGraw-Hill.

10. Murniarti (2002): “InvestigasiFaktor-Faktor yang MempengaruhiPenyiapandanInformasiAkuntansi Perusahaan Kecil danMenengah”,SimposiumFakultasEkonomiUniversitasCokrominoto Yogyakarta.

11. N. Sixpria, T. Suhartati, and S. Warsini (2013): "EvaluasiImplementasiStandarAkuntansiEntitasTanpaAkuntabilitasPublik (ETAP) danPenyusunanLaporanKeuanganAuditanpada Usaha Mikro, Kecil danMenengah (UMKM)",JurnalEkonomidanBisnis, Vol. 12, No. 1: 55-64.

12. Norkamsiah, A. I. Kesuma, andA. Setiawaty (2016):"PenerapanStandarAkuntansiKeuanganEntitasTanpaAkuntabilitasPublik (SAK ETAP) padaPenyusunanLaporanKeuangan”,Akuntabel: JurnalEkonomidanKeuangan. Vol. 13, No. 2: 151-163.

13. P. Cleary and M. Quinn (2016): "Intellectual Capital and Business Performance: An Exploratory Study of the Impact of Cloud-Based Accounting and Finance Infrastructure”,Journal of Intellectual Capital, Vol. 17, No. 2, pp. 255-278, 2016.

14. R. Kreitner and A. Kinicki (2013): “Organizational Behavior”, 10 ${ }^{\text {th }}$ Edition. New York, NY: McGraw-Hill/Irwin. (International Edition).

15. R. Rudiantoro and S.V. Siregar (2011): "KualitasLaporanKeuangan UMKM sertaProspekImplementasi SAK 
ETAP, "SimposiumNasionalAkuntansi XIV Aceh.

16. U. Sekaran and R. Bougie (2016): "Research Method for Business: Skill Building Approach”, $7^{\text {th }}$ edition. Wiley.

17. V. Diacahya (2014): "PenyusunanLaporanKeuanganBerbasisStandarAkuntansiKeuanganEntitasTanpaAkuntabilitasPublik (SAK ETAP) danUpayaPengembangan Usaha Kecil MenengahpadaPengrajin Batik”,Skripsi. UniversitasMuhammadiyah Surakarta.

18. W.I.Lestari(2006):

MempengaruhiPersepsiManajeratasInformasiAkuntansiKeuanganterhadapKeberhasilanMengelola danMenengah”,Skripsi. STIE Perbanas Surabaya.

19. Z. Hanum (2013): "PengaruhPersepsiPengusaha Kecil atasInformasiAkuntansiKeuanganterhadapKeberhasilan Perusahaan: Surveipadausaha-usahakecil di Kota Medan”,JurnalRisetAkuntansiBisnis.Vol. 13, No. 2, pp. 219-250/September 2013. 
